\title{
GENETIC GAINS IN THE POPCORN POPULATION UENF-14: DEVELOPING THE NINTH GENERATION OF INTRAPOPULATION RECURRENT SELECTION ${ }^{1}$
}

\author{
AMANDA GONÇALVES GUIMARÃES ${ }^{2}$, ANTÔNIO TEIXEIRA DO AMARAL JÚNIOR ${ }^{2}$, GUILHERME FERREIRA \\ PENA $^{2}$, JANEO EUSTÁQUIO DE ALMEIDA FILHO ${ }^{2}$, MESSIAS GONZAGA PEREIRA ${ }^{2}$, PEDRO HENRIQUE \\ ARAÚJO DINIZ SANTOS ${ }^{2}$
}

\begin{abstract}
The occurrence of negative correlations between grain yield (GY) and popping expansion (PE) in popcorn complicates the selection process. In an attempt to overcome this inconvenience, we proposed the use of the importance characteristic volume per popcorn per hectare (PV). The objectives of this study were to develop the ninth cycle of the UENF-14 popcorn population, to estimate the direct and indirect effects of PV and to verify the genetic progress among all selective cycles. We obtained and evaluated 200 inbred progenies in randomised blocks arranged in replicates within sets, with nine sets consisting of 25 progenies and one set with all previous eight cycles with three replicates. The average height of the plants, prolificacy, 100-grain weight, grain yield, grain popping expansion and volume per popcorn per hectare were evaluated. Track analysis was performed to determine the direct and indirect effects, and the Mulamba and Mock selection index was calculated for the selection of the 40 superior progenies. There was genetic variability among progenies in all evaluated traits, with a cause-and-effect relationship between PV with GY and PE, allowing simultaneous gains with indirect selection. The selection of the best progenies was more effective when using arbitrarily assigned weights, which provided higher predicted gains for PV (20.73\%). The means obtained in all cycles indicated increases, demonstrating the efficiency of using continuous recurrent selection in popcorn breeding programs.
\end{abstract}

Keywords: Zea mays L. var. everta. $\mathrm{S}_{1}$ progenies. Yield. Popping expansion. Expanded popcorn volume per hectare.

\section{GANHOS GENÉTICOS NA POPULAÇ̃̃O DE MILHO-PIPOCA UENF-14: DESENVOLVENDO A NONA GERAÇÃO DE SELEÇÃO RECORRENTE INTRAPOPULACIONAL}

RESUMO - A ocorrência da correlação negativa entre produtividade de grãos (PG) e capacidade de expansão (CE) no milho-pipoca contribui para dificultar o processo seletivo. No intento de contornar esse inconveniente, foi proposto, o caráter de importância, volume por pipoca expandida por hectare (VP). O objetivo deste estudo foi desenvolver o nono ciclo da população UENF-14 de milho-pipoca, estimar o efeito direto e indireto de VP e averiguar o progresso genéticos entre todos os ciclos seletivos. Duzentas progênies endogâmicas foram obtidas e avaliadas em blocos casualizados, com arranjos em repetições dentro de sets, sendo nove sets, oito constituídos por 25 progênies e um set com todos ciclos anteriores (oito) com três repetições. Avaliou-se a altura média da planta, prolificidade, peso de cem grãos, produtividade de grãos, capacidade de expansão e volume por pipoca expandida por hectare. Realizou-se a análise de trilha para desdobrar os efeitos diretos e indiretos e o índice de seleção Mulamba e Mock para seleção de quarenta progênies superiores. Houve variabilidade genética entre as progênies para todas características. Existe relação de causa e efeito entre o VP com a PG e CE, permitindo ganhos simultâneos com a seleção indireta. A seleção das progênies superiores com a utilização do peso atribuído por alternativas proporcionou maiores ganhos preditos de VP (20,73\%). As médias obtidas em todos os ciclos indicaram aumentos, demonstrando a eficiência do uso da seleção recorrente em programas de melhoramento de milho-pipoca.

Palavras-chave: Zea mays L. var. everta. Progênies $\mathrm{S}_{1}$. Produtividade. Capacidade de expansão. Volume por pipoca expandida por hectare.

\footnotetext{
${ }^{*}$ Corresponding author

${ }^{1}$ Received for publication in $01 / 16 / 2018$; accepted in $06 / 17 / 2019$.

Paper extracted from the doctoral thesis of the first author.

${ }^{2}$ Center of Sciences and Agricultural Technologies, Universidade Estadual do Norte Fluminense Darcy Ribeiro, Campos dos Goytacazes, RJ, Brazil; amandagguimaraes@yahoo.com.br - ORCID: 0000-0003-0761-8287, amaraluenf@gmail.com - ORCID: 0000-0003-48317878, penabio@yahoo.com.br - ORCID: 0000-0002-9280-6911, janeoeaf@gmail.com - ORCID: 0000-0002-3906-8884, messiasgpereira@gmail.com - ORCID: 0000-0002-3463-3768, phsantos2004@yahoo.com.br - ORCID: 0000-0002-7781-215X.
}

Rev. Caatinga, Mossoró, v. 32, n. 3, p. 625 - 633, jul. - set., 2019 


\section{INTRODUCTION}

Breeding programs are constantly developed to combine several traits of interest in a single plant that would meet the demands of both producers and consumers. In this scenario, popcorn breeding relies mostly on the key traits of grain yield and popping expansion; however, there is the recurring of negative correlations between these two traits (SCAPIM et al., 2012; CABRAL et al., 2016).

In the case of popcorn, selecting superior progenies is not an easy task, since the key traits are quantitatively inherited and controlled by several genes, as for example yield and popping expansion (ZEIGLER, 2000). The methodology of recurrent selection is the main alternative, consisting of a cyclical process that increases the frequency of favourable alleles, raising the mean of the main traits without exhausting the genetic variability of the population (HALLAUER; MIRANDA FILHO; CARENA, 2010), although it is believed that the gains are no longer significantly increased in the more advanced cycles. The methodology of recurrent selection has already been used in some studies on popcorn (EMATNÉ et al., 2012; FARIA et al., 2008; GUIMARÃES et al., 2018a; LIMA et al., 2018; REIS et al., 2009; VILARINHO et al., 2002).

To select superior progenies for both key traits of interest in popcorn, a single variable was proposed as selection criterion: expanded popcorn volume per hectare (AMARAL JÚNIOR et al., 2016), representing an important characteristic that aggregates grain yield and popping expansion in combined selection. The above authors recommended this variable for popcorn breeding programs in view of the simultaneous gains in yield and popping expansion obtained by indirect selection when using expanded popcorn volume per hectare as the main trait.

For the selection of superior progenies that simultaneously carry a set of traits of economic importance, multivariate statistical procedures must be used, e.g. path analysis (CREVELARI et al., 2018; CHOTALIYA; KULKARNI, 2017) and selection index (BUZZELLO et al., 2015; CREVELARI et al., 2019). Path analysis partitions the direct and indirect effects of the study variables that influence a key variable of main interest, and the use of a selection index by which the relative merit of a series of progenies can be determined, constituting a basis to differentiate the progenies (CRUZ; REGAZZI; CARNEIRO, 2012) and thus to select the best ones that compose the next selection cycle (LIMA et al., 2018; SILVA et al., 2018).

In view of the need to select superior popcorn progenies with regard to the two traits of commercial interest (grain yield and popping expansion), as well as to mitigate the occurrence of potentially lower gains in more advanced cycles of recurrent selection, this study predicted the genetic gains with the new variable (importance character) $\mathrm{PV}$ in the ninth recurrent selection cycle for the UENF-14 popcorn population, using inbred progenies, to estimate the direct and indirect effects of PV and thus to assess the genetic progress in successive selection cycles.

\section{MATERIAL AND METHODS}

\section{Developing and evaluating UENF-14 popcorn progenies in the ninth selection cycle}

To establish 200 inbred progenies $\left(S_{1}\right)$, the seeds of 100 recombined lines from the eighth recurrent selection cycle of the UENF-14 popcorn population were sown in April 2015 in an area of the Colégio Estadual Agrícola Antônio Sarlo, in the county of Campos dos Goytacazes, RJ, Brazil. The 5 $-\mathrm{m}$ long rows were spaced $0.90 \mathrm{~m}$ apart, and the planting spots were $0.20 \mathrm{~m}$ apart; one seed per hole was inserted to a depth of $0.05 \mathrm{~m}$. The following procedure was used to obtain the inbred progenies: the ears were covered with plastic bags before releasing the stigmas to avoid contamination. As soon as the ears presented the emergence of the stigmas, the tassel was protected with Kraft paper bags, considering this phase when they were $1 / 3$ or less of the anthers open. The following day, selfpollination was carried out, and at harvest, 200 ears, which contained enough grains to separate two seed lots, were selected. One lot was evaluated in a competition test and the other one of the remaining seeds for the recombination step between progenies best.

The $200 \mathrm{~S}_{1}$ progenies were evaluated in the growing season of 2015/2016 in two environments: Antônio Sarlo State Agricultural College, in the county of Campos dos Goytacazes, RJ (21 ${ }^{\circ} 45^{\prime} \mathrm{S}$ latitude, $41^{\circ} 20^{\prime} \mathrm{W}$ longitude; $11 \mathrm{~m}$ above sea level), with a mean annual temperature of $23^{\circ} \mathrm{C}$, and at the experimental station of PESAGRO-Rio, on the island of Barra do Pomba in Itaocara, RJ (21 $1^{\circ} 39^{\prime} \mathrm{S}$ latitude, $42^{\circ} 04$ ' $\mathrm{W}$ longitude; at $60 \mathrm{~m}$ above sea level), with a mean annual temperature of $22.5^{\circ} \mathrm{C}$.

The experiment was arranged in randomised blocks with three replications within "sets" in two environments, according to the genetic-statistical model proposed by Hallauer and Miranda Filho (1981). Nine "sets" were used, of which eight comprised $25 \mathrm{~S} 1$ progenies each (totalling the 200 inbred progenies obtained for cycle nine), and one "set" comprised all previous cycles of the population UENF-14 (C0, C1, C2, C3, C4, C5, C6, C7 and C8). Each plot consisted of a $3.5-\mathrm{m}$ long row, with rows spaced $0.90 \mathrm{~m}$ and plants $0.20 \mathrm{~m}$ apart, with two seeds being inserted into each hole to a depth of 0.05 $\mathrm{m}$, resulting in 16 plants per plot and 675 plots per environment. At 21 days after emergence, thinning was performed, leaving one healthy plant per hole. Sowing fertilisation consisted of $800 \mathrm{~kg} \mathrm{ha}^{-1}$ of the 
mineral fertiliser 04-14-08 (N- $\left.\mathrm{P}_{2} \mathrm{O}_{5}-\mathrm{K}_{2} \mathrm{O}\right)$; topdressing consisted of $300 \mathrm{~kg} \mathrm{ha}^{-1}$ of the mineral fertiliser 20-00-20 ( $\left.\mathrm{N}-\mathrm{P}_{2} \mathrm{O}_{5}-\mathrm{K}_{2} \mathrm{O}\right)$ at 30 days after sowing, plus $260 \mathrm{~kg} \mathrm{ha}^{-1}$ of ammonium sulphate at 45 days after sowing. Weed, pest and disease control were carried out according to the recommendations for the crop (VITTORAZZI et al., 2013).

The following traits were evaluated: i) mean plant height $(\mathrm{PH})$, by measuring six plants from the ground level to the point of flag leaf insertion (in $\mathrm{cm}$ ); ii) prolificacy (PRL), by counting the number of ears per plant; iii) 100-grain weight $(100 \mathrm{GW}$; in $\mathrm{g})$, by weighing 100 randomly collected seeds on an analytical balance, in three replications per plot; iv) grain yield (GY), obtained by measuring grain yield per plot (in $\mathrm{kg} \mathrm{ha}{ }^{-1}$ ); v) popping expansion (PE), for which a sample of $30 \mathrm{~g}$ of grains was selected by sieving in a seed sorter (Vence Tudo ${ }^{\circledR}$ ) with oblong holes (diameter between 5 and $5.5 \mathrm{~mm}$ to ensure a standard grain size) and heated in a microwave oven in a Kraft paper bag without oil for $2 \mathrm{~min}$; the expanded popcorn volume was measured in a 2,000-mL beaker, determining the quotient by dividing the popcorn volume by 30 (in $\mathrm{mL} \mathrm{g}^{-1}$ ), in three replications per plot; iv) expanded popcorn volume per hectare (PV), calculated by multiplying the mean plot yield by the popping expansion, generating a importance characteristic as selection criterion for the two main traits (in $\mathrm{m}^{3} \mathrm{ha}^{-1}$ ).

\section{Statistical analysis}

Analysis of variance was performed separately for each environment to test for homogeneity of residual variances by the relation between the largest and the smallest mean squares for the environmental error in all traits (GOMES; GARCIA, 2002). Subsequently, analysis of combined variance was performed, based on the genetic-statistical model proposed by Hallauer and Miranda Filho (1981): $Y_{i j k l}=\mu+A_{i}+S_{j}+A S_{i j}+R / A S_{i j k}+P / S_{j l}+A P / S_{i j l}+e_{i j k l}$ where $\mu$ is the mean, $A_{i}$ the fixed effect of the $\mathrm{i}^{\text {-th }}$ environment, $S_{j}$ is the effect of the $\mathrm{j}^{\text {-th }}$ "set" $A S_{i j}$ is the effect of the interaction between environments and "set"s, $R / A S_{i j k}$ is the effect of the $\mathrm{k}^{\text {-th }}$ replication within the interaction between the $\mathrm{i}^{\text {-th }}$ environment and the $\mathrm{j}^{\text {-th }}$ "set"; $P / S_{j l}$ is the random effect of the $i^{- \text {th }}$ progeny within the $j^{\text {-th }}$ "set", assumed as independent and normally distributed, with mean 0 and constant variance $\sim \operatorname{NID}\left(0, \sigma_{\mathrm{P}}^{2}\right)$, $A P / S_{i j l}$ is the effect of the environment - progeny interaction within the $\mathrm{j}^{\text {-th }}$ "set" and $e_{i j k l}$ is the experimental error associated with observation $\mathrm{Y}_{\mathrm{ijk} \mathrm{k}}$, $\mathrm{e}_{\mathrm{ijk}} \sim$ NID $\left(0, \sigma^{2}\right)$. All sources of variation, except environment, were considered random. Based on the proposed model, the SAS ${ }^{\circledR}$ Program (SAS 9.1, SAS Institute, Cary, NC, USA) was used for analysis of variance.
After establishing the mean squares, the genetic parameters were determined by combined analysis: coefficient of experimental variation: $\mathrm{CV}_{\mathrm{e}}(\%)=100 \frac{\overline{\sigma_{\mathrm{e}}^{2}}}{\mu}=\frac{\overline{\mathrm{RMS}}}{\mu}$ in which $\sigma_{\mathrm{e}}^{2}=$ residual mean variance, $\mathrm{RMS}=$ residual mean square and $\mu=$ mean.

Coefficient of genetic variation:

$\mathrm{CV}_{\mathrm{g}}(\%)=100 \frac{\overline{\sigma_{\mathrm{g}}^{2}}}{\mu}=100 \frac{\overline{\mathrm{MSP} / \mathrm{S}-\mathrm{RMS} / \mathrm{er}}}{\mu}$

where $\sigma_{\mathrm{g}}^{2}=$ genotypic variation among progenies, $\mu=$ mean, $\mathrm{MSP} / \mathrm{S}=$ mean squares of progenies within the "sets", RMS = residual mean square and e $=$ number of environments, $\mathrm{r}=$ number of repetitions.

Heritability on a progeny mean basis $h_{\bar{X}}^{2}=\frac{\sigma_{G}^{2}}{\sigma_{\bar{F}}^{2}}=\frac{Q M P / S-Q M R}{Q M P / S}$, where $\sigma_{G}^{2}=$ genotypic variation among progenies and $\sigma_{\bar{F}}^{2}=$ phenotypic variation among progenies.

Variation index: $\mathrm{I}_{\mathrm{v}}=\frac{\mathrm{CV}_{\mathrm{g}}}{\mathrm{CV}_{\mathrm{e}}}$, where $\mathrm{CVg}=$ coefficient of genetic variation and $\mathrm{CVe}=$ coefficient of experimental variation (FREITAS et al., 2014).

In the path analysis, for the partitioning of the direct and indirect effects, the genotypic correlation between the dependent variable and the explanatory variables was estimated using the equation: $r_{i x}=P_{i x}+\sum_{j \neq i}^{n} r_{j} P_{j x}$ explanatory variable, $P_{i x}$ is the direct effect of variable $\mathbf{i}$ on the dependent variable, $r_{j} P_{j x}$ the indirect effect of variable $\mathbf{i}$, via variable $\mathbf{j}$, on the dependent variable. The underlying hypotheses for path analysis were as follows: the traits GY, PE and $\mathrm{PV}$ as main variables and the others as explanatory variables.

For the selection of the 40 best $S_{1}$ progenies and to calculate the predicted gains for the ninth cycle, the selection index of Mulamba and Mock (1978) was used as it resulted in higher gains for grain expansion and yield than the other indices evaluated for popcorn in other works (RIBEIRO et al., 2012). The economic weights suggested by Cruz, Regazzi and Carneiro (2012), provided by analysis of variance, were coefficient of genetic variation $(\mathrm{CVg})$, variation index (Iv) and heritability estimate $\left(\mathrm{h}^{2}\right)$ of each variable, as well as arbitrarily assigned weights (AW), at weights of $1,1,1$ and 10 , respectively, for $\mathrm{PH}$, PRL, $100 \mathrm{GW}$ and $\mathrm{PV}$, after several arbitrary attempts, using the software Genes (CRUZ, 2013).

The means of the checks in all recurrent selection cycles of the population UENF-14 and the predicted means of the 40 best progenies of the ninth 
cycle (means of the two environments) were estimated by a simple linear regression equation, where the variable expanded popcorn volume was considered as dependent and the cycles were considered as independent variables.

\section{RESULTS AND DISCUSSION}

Population traits and genetic parameters in the ninth selection cycle of population UENF-14

The population characteristics, measures of genetic parameters, variability, as well as the environmental effect, and the data quality of the population evaluated are important for breeders. This information assists them in choosing breeding strategies for the selection of superior genotypes and in developing new varieties for producers (GUIMARÃES et al., 2018a). The individual analysis of variance of each environment was carried out and showed homogeneity of residual variancesratio between highest and lowest mean squares of the residue lower than seven (GOMES; GARCIA, 2002) in all characteristics; subsequently, the joint analysis of variance was performed.

The environment had a significant $(\mathrm{p}<0.01)$ influence on the evaluated $\mathrm{S}_{1}$ progenies in all traits, indicating environmental differences between Campos dos Goytacazes and Itaocara. The mean performance for all traits was better in the environment of Itaocara than in Campos dos Goytacazes, with the exception of PE, with a mean of $34.54 \mathrm{~mL} \mathrm{~g}^{-1}$ in the latter and $31.89 \mathrm{~mL} \mathrm{~g}^{-1}$ in the former. This may be due to the fact that in Campos dos Goytacazes, strong winds are common and may have caused tipping of the plants, ceasing the translocation of photoassimilates and resulting in lower plant height, prolificacy, 100-grain weight and grain yield. Another explanation may be the polygeneity of $\mathrm{PE}$, as suggested by some authors (ZEIGLER, 2000). In addition, the inbred progenies used may have favoured the expression of recessive alleles and thus intensified the environmental effects, resulting in a greater discrepancy in phenotypic expression (Table 1).

Table 1. Estimates of mean squares, means and genetic parameters of seven traits evaluated in two environments for 200 inbred progenies in the ninth recurrent selection cycle of the UENF-14 popcorn population. Campos dos Goytacazes and Itaocara, RJ, growing season 2015/2016.

\begin{tabular}{|c|c|c|c|c|c|c|c|}
\hline \multirow{2}{*}{ SV } & \multirow{2}{*}{$\mathrm{DF}$} & \multicolumn{6}{|c|}{$\mathrm{MS} /{ }^{1}$} \\
\hline & & $\mathrm{PH}$ & PRL & $100 \mathrm{GW}$ & GY & $\mathrm{PE}$ & PV \\
\hline Environment (E) & 1 & $963,258.17^{* *}$ & $15.38^{* *}$ & $285.12^{* *}$ & $152,805,766.7^{* *}$ & $1,980.15^{* *}$ & $100,144.19^{* *}$ \\
\hline Set (S) & 7 & $1,341.43^{* *}$ & $0.35^{* *}$ & $21.43^{* *}$ & $1,835,685.5^{* *}$ & $34.92^{* *}$ & $1,943.38^{* *}$ \\
\hline $\mathrm{E} \times \mathrm{S}$ & 7 & $1,084.05^{* *}$ & $0.08^{\mathrm{ns}}$ & $6.7^{* *}$ & $694,529.1^{* *}$ & $23.35^{* *}$ & $796.95^{* *}$ \\
\hline $\operatorname{Rep}(\mathrm{R}) / \mathrm{E} \times \mathrm{S}$ & 32 & $214.8^{* *}$ & $0.09^{* *}$ & $1.28^{\mathrm{ns}}$ & $112,406^{* *}$ & $5.53^{\mathrm{ns}}$ & $125.32^{* *}$ \\
\hline Progeny $(\mathrm{P}) / \mathrm{S}$ & 192 & $415.41^{* *}$ & $0.14^{* *}$ & $7.41^{* *}$ & $716,288.1^{* *}$ & $43.62^{* *}$ & $899.31^{* *}$ \\
\hline $\mathrm{E} \times \mathrm{P} / \mathrm{S}$ & 192 & $206.07^{* *}$ & $0.10^{* *}$ & $3.06^{* *}$ & $519,336.3^{* *}$ & $29.69^{* *}$ & $679.16^{* *}$ \\
\hline Errors & 768 & 85.29 & 0.05 & 1.13 & $60,254.30$ & 4.660 & 69.010 \\
\hline Mean & & 164.04 & 0.97 & 11.42 & $2,763.50$ & 33.20 & 51.87 \\
\hline Itaocara mean & & 192.21 & 1.09 & 11.88 & $3,122.28$ & 31.89 & 110.19 \\
\hline C. G. $/{ }^{2}$ mean & & 135.40 & 0.86 & 10.91 & $2,401.04$ & 34.54 & 83.14 \\
\hline \multicolumn{8}{|l|}{$\begin{array}{c}\text { Genetic } \\
\text { parameters }{ }^{\beta}\end{array}$} \\
\hline $\mathrm{CV}_{\mathrm{e}}$ & - & 5.63 & 23.96 & 9.31 & 8.88 & 6.50 & 16.02 \\
\hline $\mathrm{CV}_{\mathrm{g}}$ & - & 4.52 & 12.34 & 8.96 & 11.97 & 7.68 & 22.68 \\
\hline $\mathrm{I}_{\mathrm{v}}$ & - & 0.80 & 0.52 & 0.96 & 1.35 & 1.18 & 1.42 \\
\hline$h^{2}$ & - & 0.79 & 0.61 & 0.84 & 0.91 & 0.89 & 0.92 \\
\hline
\end{tabular}

${ }^{1 /} \mathrm{PH}=$ mean plant height $(\mathrm{cm}) ; \mathrm{PRL}=$ prolificacy; 100GW = 100-grain weight $(\mathrm{g}) ; \mathrm{GY}=$ grain yield $\left(\mathrm{kg} \mathrm{ha}^{-1}\right) ; \mathrm{PE}=$ popping expansion $\left(\mathrm{mL} \mathrm{g}^{-1}\right) ; \mathrm{PV}=$ expanded popcorn volume per hectare $\left(\mathrm{m}^{3} \mathrm{ha}^{-1}\right)$.

${ }^{2 /} \mathrm{C} . \mathrm{G}=$ Campos dos Goytacazes

${ }^{3 /} \mathrm{CVe}=$ coefficient of experimental variation; $\mathrm{CVg}=$ coefficient of genotypic variation; $\mathrm{Iv}=$ variation index; $\mathrm{h}^{2}=$ heritability on a progeny mean basis;

ns $^{* *},{ }^{*}=$ non-significant, significant at $\mathrm{P}<0.01$ and $\mathrm{P}<0.05$, respectively, by the $\mathrm{F}$ test. 
There was a highly significant effect $(\mathrm{p}<$ 0.01 ) for all traits on the source of variation for "sets", progenies within "sets" and environment versus progenies within "sets". These differences indicate an expression of sustainable variability among progenies, since each "set" has a distinct group of progenies, and therefore, the absence of this design in "sets" would probably produce variations due to the high number of evaluated progenies (200), which could overestimate the genetic variability due to a heterogeneous local and lead to a loss of experimental precision (RANGEL et al., 2011). This genetic variability among the progenies is indispensable for the successful selection of superior progenies, to achieve selection gains and to improve the population (RAMALHO et al., 2012). This high significance of all traits in all environments also indicates the exposure of previously hidden alleles in the heterozygotes, resulting from the higher inbreeding level with the establishment of the $\mathrm{S}_{1}$ family structure, thereby causing great variability among the progenies. The differences in progeny led to different results within the respective set of environmental conditions; however, the progenies were selected for both environments allowing a reduction of recurrent selection cost.

Regarding the mean values obtained in this ninth recurrent selection cycle of the UENF-14 popcorn population (Table 1), compared to the previous cycle, there was a decrease in prolificity by $23.62 \%$, in weight of 100 grains by $2.89 \%$ and in yield by $10.73 \%$ (GUIMARÃES et al., 2018a). This was expected, since in this study, we used $S_{1}$ progenies and, in the previous cycle, full-sibs. The higher inbreeding level in the ninth cycle possibly caused an increase in the frequency of homozygous plants, resulting in a reduction in the population mean (ARNHOLD et al., 2010; RAMALHO et al., 2012). However, with the recombination of the 40 best progenies, the population potential is expected to be restored by increasing the frequency of favourable alleles, since theoretical comparisons between different recurrent selection methods indicated that selection based on $\mathrm{S}_{1}$ progenies is more efficient in increasing the frequency of favourable alleles, especially when the trait has a dominance effect.

In spite of the structure of the $S_{1}$ families used, there was no change in mean $\mathrm{PE}$ with the increasing inbreeding rate, maybe because this trait has a predominantly additive effect (PEREIRA; AMARAL JÚNIOR, 2001). Thus, Scapim et al. (2012) investigated inbreeding depression in popcorn populations and concluded that the variation and level of inbreeding depression for the trait PE are much lower - 7.2 to $14.3 \%$ - than for grain yield 10.5 to $45.2 \%$, which can be explained by the lower genetic complexity of the trait and by the predominance of additive gene effects (homozygous loci).

The adjusted CVes were proposed by Fritsche -Neto et al. (2012) for maize. Based on the proposal of these authors, the $\mathrm{CVe}$ for the trait prolificacy was considered high (19.27 to $25.81 \%$ ), while for mean plant height (3.56 to $8.25 \%$ ), yield (8.25 to $15.49 \%$ ) and 100-grain weight (4.82 to $20.04 \%$ ), the estimates were considered moderate, that is, the lower the CVes values, the better the accuracy of the data, since they indicate the quality of the data and to which extent the environment interferes with the evaluations. A better accuracy of the data in the present research was demonstrated in relation to the previous cycle for the main characteristics; the yield and capacity expansion CVe of 8.88 and $6.50 \%$ respectively, already in the eighth cycle in this same order, were 18.52 and $13.81 \%$, as presented by Guimarães et al. (2018a).

The Iv estimates were considered high for the most relevant traits (GY 1.35 and PE 1.18) as well as for PV (1.34), denoting that the environmental values are overlayered by the genetic values, making the selection for these key traits successful. For these traits, heritability estimates were also high due to better data quality with better chances of selecting the best.

Genetic gains and potential progenies in the ninth selection cycle of the UENF-14 popcorn population

Based on path analysis with GY as key trait, most traits (except PV) had a low direct effect on grain yield, indicating that an intensified selection pressure on any of these would not result in satisfactory yield gains (Table 2). The negative estimates for PE, for both direct and indirect effects, confirmed the negative correlation between these two traits, a fact that complicates simultaneous gains, requiring the use of genetic-statistical procedures by which the deleterious effects of the correlated response can be minimised (SCAPIM et al., 2012; CABRAL et al., 2016). An alternative is the use of the selection index Mulamba and Mock (1978), in which it is based on the sum of points and consists of classifying the genotypes in relation to each one of the characteristics in a favourable order of improvement. However, with the use of variable PV, the estimates of the direct effect and the correlation coefficient were high (1.046 and 0.948, respectively), favouring the use of PV to maximise selection. 
A. G. GUIMARÃES et al.

Table 2. Partitioning of genotypic correlations in components of direct and indirect effects, involving the main dependent variables grain yield (GY), popping expansion (PE) and expanded popcorn volume per hectare (PV) and the independent explanatory variables evaluated in $200 \mathrm{~S}_{1}$ progenies in the ninth recurrent selection cycle of the popcorn population UENF14. Campos dos Goytacazes and Itaocara, RJ, growing season 2015/2016.

\begin{tabular}{|c|c|c|c|c|c|}
\hline Main: GY & & Main: PE & & Main: PV & \\
\hline $\mathrm{PH}$ & & $\mathrm{PH}$ & & $\mathrm{PH}$ & \\
\hline Direct effect on GY & 0.013 & Direct effect on PE & 0.051 & Direct effect on PV & -0.014 \\
\hline Indirect effect via PRL & 0.004 & Indirect effect via PRL & 0.007 & Indirect effect via PRL & -0.002 \\
\hline Indirect effect via $100 \mathrm{GW}$ & 0.004 & Indirect effect via $100 \mathrm{GW}$ & 0.008 & Indirect effect via $100 \mathrm{GW}$ & -0.002 \\
\hline Indirect effect via PE & -0.032 & Indirect effect via GY & -0.070 & Indirect effect via GY & 0.024 \\
\hline Indirect effect via PV & 0.038 & Indirect effect via PV & 0.104 & Indirect effect via PE & 0.030 \\
\hline Total & 0.027 & Total & 0.101 & Total & 0.036 \\
\hline PRL & & PRL & & PRL & \\
\hline Direct effect on GY & 0.068 & Direct effect on PE & 0.119 & Direct effect on PV & -0.035 \\
\hline Indirect effect via $\mathrm{PH}$ & 0.000 & Indirect effect via PH & 0.030 & Indirect effect via $\mathrm{PH}$ & -0.001 \\
\hline Indirect effect via $100 \mathrm{GW}$ & -0.003 & Indirect effect via $100 \mathrm{GW}$ & -0.005 & Indirect effect via $100 \mathrm{GW}$ & 0.015 \\
\hline Indirect effect via PE & -0.063 & Indirect effect via GY & -1.972 & Indirect effect via GY & 0.689 \\
\hline Indirect effect via PV & 0.748 & Indirect effect via PV & 2.051 & Indirect effect via PE & 0.060 \\
\hline Total & 0.751 & Total & 0.197 & Total & 0.715 \\
\hline $100 \mathrm{GW}$ & & $100 \mathrm{GW}$ & & $100 \mathrm{GW}$ & \\
\hline Direct effect on GY & 0.034 & Direct effect on PE & 0.070 & Direct effect on PV & -0.021 \\
\hline Indirect effect via $\mathrm{PH}$ & 0.001 & Indirect effect via PH & 0.006 & Indirect effect via $\mathrm{PH}$ & -0.016 \\
\hline Indirect effect via PRL & -0.005 & Indirect effect via PRL & -0.009 & Indirect effect via PRL & 0.003 \\
\hline Indirect effect via PE & -0.033 & Indirect effect via GY & -0.65 & Indirect effect via PE & 0.228 \\
\hline Indirect effect via GY & 0.257 & Indirect effect via PV & 0.688 & Indirect effect via GY & 0.032 \\
\hline Total & 0.249 & Total & 0.103 & Total & 0.240 \\
\hline $\mathrm{PE}$ & & GY & & GY & \\
\hline Direct effect on GY & -0.320 & Direct effect on PE & -2.624 & Direct effect on PV & 0.918 \\
\hline Indirect effect via PH & 0.001 & Indirect effect via PH & 0.013 & Indirect effect via $\mathrm{PH}$ & -0.000 \\
\hline Indirect effect via PRL & 0.013 & Indirect effect via PRL & 0.090 & Indirect effect via PRL & -0.027 \\
\hline Indirect effect via $100 \mathrm{GW}$ & 0.004 & Indirect effect via $100 \mathrm{GW}$ & 0.018 & Indirect effect via $100 \mathrm{GW}$ & -0.005 \\
\hline Indirect effect via PV & 0.508 & Indirect effect via PV & 2.722 & Indirect effect via PE & 0.063 \\
\hline Total & 0.206 & Total & 0.206 & Total & 0.948 \\
\hline PV & & PV & & $\mathrm{PE}$ & \\
\hline Direct effect on GY & 1.046 & Direct effect on PE & 2.870 & Direct effect on PV & 0.307 \\
\hline Indirect effect via $\mathrm{PH}$ & 0.000 & Indirect effect via $\mathrm{PH}$ & 0.002 & Indirect effect via PH & -0.001 \\
\hline Indirect effect via PRL & 0.049 & Indirect effect via PRL & 0.085 & Indirect effect via PRL & -0.007 \\
\hline Indirect effect via $100 \mathrm{GW}$ & 0.008 & Indirect effect via $100 \mathrm{GW}$ & 0.017 & Indirect effect via $100 \mathrm{GW}$ & -0.002 \\
\hline Indirect effect via $\mathrm{PE}$ & -0.155 & Indirect effect via GY & -2.489 & Indirect effect via GY & 0.189 \\
\hline Total & 0.948 & Total & 0.485 & Total & 0.485 \\
\hline Coefficient of determination & 0.986 & Coefficient of determination & 0.888 & Coefficient of determination & 0.988 \\
\hline Residual effect & 0.117 & Residual effect & 0.335 & Residual effect & 0.109 \\
\hline
\end{tabular}

$\mathrm{PH}=$ mean plant height; $\mathrm{PRL}=$ prolificacy; $100 \mathrm{GW}=100$-grain weight; $\mathrm{GY}=$ grain yield; $\mathrm{PE}=$ popping expansion; $\mathrm{PV}=$ expanded popcorn volume per hectare. 
The trait PE, as the main variable, had low and negative direct and indirect effects on GY, reinforcing the negative correlation between both (Table 2). For the other traits (except for PV), the total correlations were lower than the estimate of the residual effect $(+0.34)$, which implies that an increase in popping expansion is not a cause-effect relationship with these variables. However, with PV as explanatory trait, the direct and indirect values were high, and the total correlation (0.48) was higher than the residual effect, indicating this option as advantageous for indirect selection.

The use of the variable PV as main and the other variables as explanatory traits (exceptions GY and PE), led to lower direct effects than the residual variable, as similarly observed for GY and PE when used as main variables (Table 2). Thus, narrow selection must be applied to eliminate undesirable indirect effects and to exploit the existing direct effect. Thus, in the selection of the best progenies, we should prioritise larger weights and superior improvement sense for GY and PE in the selection index Mulamb and Mock (1978). The traits PE and GY had high direct and indirect effects on PV and a high total positive correlation, confirming that both explained almost all of the variation of trait PV (coefficient of determination of 0.98).

Based on the results of the path analysis, the trait PV was used to substitute GY and PE, and thus, the genetic gains for each genetic parameter were estimated using the selection index of Mulamba and Mock (1978) to select the 40 best progenies (Table 3).

Table 3. Percentage gain estimates calculated based on the Mulamba and Mock selection index with different economic weights in the ninth recurrent selection cycle of the UENF-14 popcorn population. Campos dos Goytacazes and Itaocara, RJ, growing season 2015/2016.

\begin{tabular}{ccccc}
\hline & \multicolumn{4}{c}{ Mulamba and Mock $^{\prime 1}(\%)$} \\
\cline { 2 - 5 } Traits & $\mathrm{CVg}$ & $\mathrm{Iv}$ & $\mathrm{h}^{2}$ & $\mathrm{AW}$ \\
\hline Plant height (PH) & -1.5 & -2.78 & $-3,39$ & 0.60 \\
Prolificacy (PRF) & -6.19 & 2.07 & -1.09 & 6.08 \\
100-grain weight (100GW) & -3.59 & -5.52 & -6.04 & 2.73 \\
Expanded popcorn volume per hectare (PV) & 4.88 & 8.92 & 3.90 & 20.73 \\
\hline
\end{tabular}

${ }^{1 /} \mathrm{CVg}=$ coefficient of genetic variation; $\mathrm{Iv}=$ index of variation; $\mathrm{h}^{2}=$ heritability; and $\mathrm{AW}=$ arbitrarily assigned weights $(1,1,1,10$, for $\mathrm{PH}, \mathrm{PRF}, 100 \mathrm{GW}$ and $\mathrm{PV}$, respectively).

It is important to mention that in relation to the economic weights $\mathrm{CVg}$, Iv and $\mathrm{h}^{2}$, negative gains for mean plant height are desirable to avoid taller plants, since strong winds frequently occur in this region, potentially causing crop lodging. However, the same estimators also provided predicted negative gains for the trait 100-grain weight, which may have contributed to the lower grain yield gains; in addition, they resulted in lower gains in PV than when using arbitrarily assigned weights (AW).

When using arbitrarily assigned weights (AW), a small gain (close to zero) for mean plant height also resulted in higher gains for PV (20.73\%), making the economic weight the most indicated factor for the selection of the 40 best progenies. Parallel to the genetic gains obtained in the previous cycle ( $4.60 \%$ for GY and $3.61 \%$ for PE) (GUIMARÃES et al., 2018a), the gains predicted in this study for PV were higher. One of the reasons is the structure applied to obtain $S_{1}$ progenies in the ninth cycle, compared to full-sibs in the eighth, confirming the previous proposal of Pereira and Amaral Júnior (2001), based on an evaluation of the original population
UENF-14 by the analysis of Comstock and Robinson (1948), who detected the greatest influence of additive variance by using higher-level inbreeding systems (HALLAUER; MIRANDA FILHO; CARENA, 2010).

Genetic progress in the selection cycles of population UENF-14.

With the selection of the best $40 \mathrm{~S}_{1}$ progenies in the ninth cycle by means of the arbitrarily assigned economic weights, the genetic progress could be estimated in comparison with the other controls of the previous cycles of the same population UENF-14 (Figure 1). Between the eighth and the ninth cycle, an increase by $6.32 \mathrm{~m}^{3} \mathrm{ha}^{-1}$ per cycle in expanded popcorn volume per hectare was observed. By this comparison, it is expected that with the recombination of the 40 best progenies in the ninth cycle, the trait PV will tend to express estimates exceeding the predicted values (estimated at $112.55 \mathrm{~m}^{3} \mathrm{ha}^{-1}$ ), thus favouring sustainable gains in the next recurrent selection cycle. 


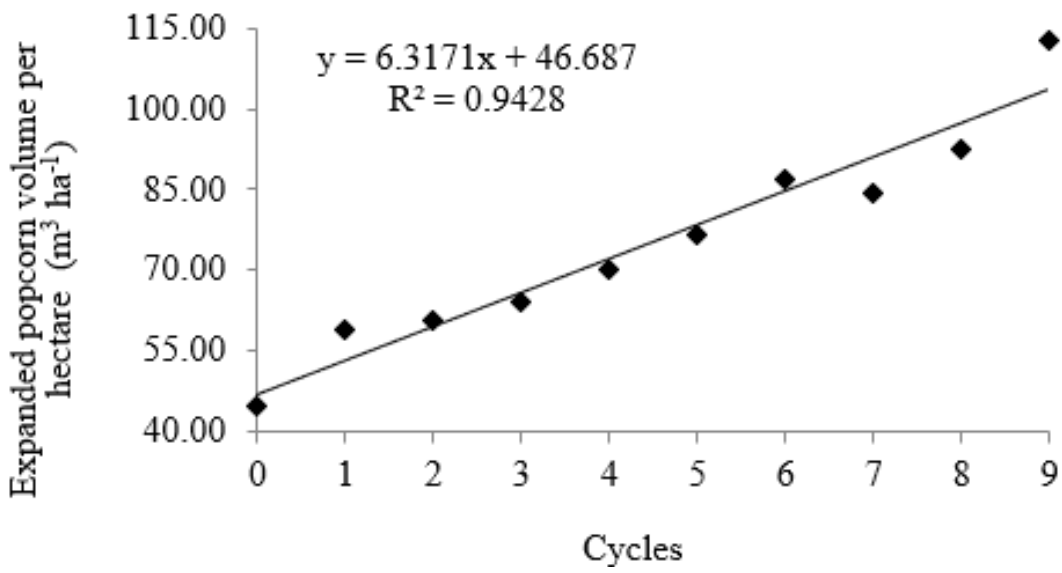

Figure 1. Means of all cycles (C0 to $\mathrm{C} 8)$ and of the predicted mean 40 progenies selected in $\mathrm{C} 9$ for the trait expanded popcorn volume per hectare $\left(\mathrm{m}^{3} \mathrm{ha}^{-1}\right)$.

These results indicate that even with the use of different progeny strategies (full-sibs, $S_{1}$ and halfsibs), there was an increase in allele frequencies for the traits of interest, with greater adaptability to counties in the north and northwest of the State of Rio de Janeiro. This progress has been described by Ribeiro et al. (2016) and Guimarães et al. (2018b). While the first authors investigated cumulative gains in GY and PE based on phenotypic responses in the same study population over seven cycles ( $\mathrm{C} 0-\mathrm{C} 6)$, the latter authors used microsatellite molecular markers (EST-SSRs), inferring an increase in favourable alleles over nine selection cycles $(\mathrm{C} 0$ $\mathrm{C} 8$ ), which may be related to the main traits of interest.

\section{CONCLUSIONS}

There was genetic variability among progenies in all evaluated traits. The direct or indirect effects of the trait expanded popcorn volume per hectare provided the best estimates to explain grain yield and popping expansion.

The selection of the best progenies was more effective when using arbitrarily assigned weights by the Mulamba and Mock index, which provided higher predicted gains for expanded popcorn volume per hectare.

The gains predicted obtained in cycle nine indicated increases in the main characteristics, demonstrating the efficiency of using continuous recurrent selection in popcorn breeding programs.

\section{ACKNOWLEDGEMENTS}

The authors are indebted to the Coordination for the Improvement of Higher Education Personnel (CAPES) - Financing Code 001 - for providing a scholarship to the first author and to the Foundation for Research Support of the State of Rio de Janeiro (FAPERJ) for funding this research.

\section{REFERENCES}

AMARAL JÚNIOR, A. T. et al. Proposal of a super trait for the optimum selection of popcorn progenies based on path analysis. Genetics and Molecular Research, v. 15, n. 4, p. 1-9, 2016.

ARNHOLD, E. et al. Inbreeding depression and genetic components for popping expansion and other traits in Brazilian populations of popcorn. Ciencia e Investigación Agraria, v. 37, n. 3, p. 125-132, 2010 .

BUZZELLO, G. L. et al. Índices não paramétricos estimados pela combinação de diferentes caracteres com acumulação de biomassa como critério de avaliação da competição de cultivares de soja com e sem sombreamento. Revista Brasileira de Biometria, v. 33, n.3, p. 310-329, 2015.

CABRAL, P. D. S. et al. Relação de causa e efeito de caracteres quantitativos sobre a capacidade de expansão do grão em milho-pipoca. Revista Ciência Agronômica, v. 47, n. 1, p. 108-117, 2016.

CHOTAliYA, P.; KULKARNI, G. U. Character association and path analysis for quantitative traits in garlic (Allium sativum L.). International Journal of Current Microbiology and Applied Sciences, v. 6, n. 8, p. 175-184. 2017.

COMSTOCK, R. E.; ROBINSON, H. F. The components of genetic variance in populations of biparental progenies and their use in estimating the average degree of dominance. Biometrics, v. 4, n. 4 , p. 254-266, 1948.

CREVELARI, J. A. et al. Correlations between agronomic traits and path analysis for silage production in maize hybrids. Bragantia, v. 77 , n. 2 , p. 243-252, 2018.

CREVELARI, J. A. et al. Genetic improvement of 
silage maize: predicting genetic gain using selection indexes and best linear unbiased prediction. Revista Ciência Agronômica, v. 50, n. 2, p. 197-204, 2019.

CRUZ, C. D; REGAZZI, A. J.; CARNEIRO, P. C. S. Modelos biométricos aplicados ao melhoramento genético. 4. ed. Viçosa, MG: UFV, 2012. 514 p.

CRUZ, C. D. Genes: a software package for analysis in experimental statistics and quantitative genetics. Acta Scientiarum Agronomy, v. 35, n. 3, p. 271276, 2013.

EMATNÉ, H. J. et al. Genetic progress of phenotypic recurrent selection in popcorn Ciência \& Agrotecnologia, v. 36, n. 1, p. 25-30, 2012.

FARIA, V. R. et al. Seleção recorrente recíproca na obtenção de híbridos interpopulacionais de milhopipoca. Pesquisa Agropecuária Brasileira, v. 43, n. 12, p. 1749-1755, 2008.

FREITAS, I. L. J. et al. Genetic gains in the UENF14 popcorn population with recurrent selection. Genetics and Molecular Research, v. 13, n. 1, p. 518-527, 2014.

FRITSCHE-NETO, R, et al. Updating the ranking of the coefficients of variation from maize experiments. Acta Scientiarum Agronomy, v. 34, n. 1, p. 99-101, 2012.

GOMES, F. P.; GARCIA, C. H. Estatística aplicada a experimentos agronômicos e florestais. Piracicaba, SP: FEALQ, 2002. 309 p.

GUIMARÃES, A. G. et al. Genetic gains and selection advances of the UENF-14 popcorn population. Revista Caatinga, v. 31 n. 2, p. 271 278, 2018a.

GUIMARÃES, A. G. et al. Population structure and impact of recurrent selection on popcorn by ESTSSR markers. Acta Scientiarum Agronomy, v. 40, n. 1, p. $33-42,2018$ b.

HALLAUER A. R.; MIRANDA FILHO, J. B.; CARENA, M. J. Quantitative genetics in maize breeding. New York: Springer, 2010. 663 p.

HALLAUER, A. R.; MIRANDA FILHO, J. B. Quantitative genetics in maize breeding. Ames: Iowa State University, 1981. 468 p.

LIMA, V. J. et al. Genetic gain capitalization in the first cycle of recurrent selection in popcorn at Ceará's Cariri. Revista Brasileira de Ciências Agrárias, v. 13, n. 3, p. 1-7, 2018
MULAMBA, N. N.; MOCK, J. J. Improvement of yield potential of the Eto Blanco maize (Zea mays L.) population by breeding for plant traits. Egyptian Journal of Genetics and Cytology, v. 7, n. 1, p. 40$51,1978$.

PEREIRA, M. G.; AMARAL JÚNIOR, A. T. Estimation of genetic components in popcorn based on the nested design. Crop Breeding and Applied Biotechnology, v. 1, n. 1, p. 3-10, 2001

RAMALHO, M. A. P. et al. Genética na Agropecuária. 5. ed. Lavras, MG: UFLA, 2012. 566 p.

RANGEL, R. M. et al. Análise biométrica de ganhos por seleção em população de milho pipoca de quinto ciclo de seleção recorrente. Revista Ciência Agronômica, v. 42, n. 2, p. 473-481, 2011.

REIS, M. C. et al. Progresso genético com a seleção recorrente recíproca para híbridos interpopulacionais de milho. Pesquisa Agropecuária Brasileira, v. 44, n. 12, p. 1667-1672, 2009.

RIBEIRO, R. M. et al. Genetic progress in the UENF -14 population of popcorn under recurrent selection in Rio de Janeiro. Genetics and Molecular Research, v. 11, n. 2, p. 1417-1423, 2012.

RIBEIRO, R. M. et al. Effect of recurrent selection on the variability of the UENF-14 popcorn population. Crop Breeding Applied Biotechnology, v. 16, n. 2, p. 123-131, 2016.

SCAPIM, C. A. et al. Correlations between the stability and adaptability statistics of popcorn cultivars. Euphytica, v. 174, n. 2, p. 209-218, 2012.

SILVA, J. D. L. et al. Selection for the development of black eye cowpea lines. Revista Caatinga, v. 31, n. 1, p. 72- 79, 2018.

VILARINHO, A. A. et al. Seleção de progênies endogâmicas S1 e S2 em um programa de melhoramento intrapopulacional de milho pipoca. Acta Scientiarum, v. 24, n. 5, p. 1419-1425, 2002.

VITTORAZZI, C. et al. Selecting pre-cultivars of popcorn maize based on nonparametric indices. Revista Ciência Agronômica, v. 44, n. 2, p. 356362,2013

ZEIGLER, K. E. Popcorn. In: HALLAUER, A. R. (Ed.). Specialty Corns. Boca Raton: CRC Press; 2000, v. 2, cap. 7, p. 199-224. 